F. Reprod. Fert. (1968) 17, 315-318

\title{
DECIDUAL REACTION IN TWO INBRED MOUSE STRAINS AND $F_{1}$ HYBRIDS
}

\author{
ANDRZEJ BARTKE* \\ Department of Animal Genetics, Fagiellonian University, Kraków, Poland
}

(Received 22nd November 1967)

\begin{abstract}
Summary. Decidual cell reaction (DCR) of the endometrium to mechanical trauma applied on the 4th day of pseudopregnancy was compared in two inbred strains $\mathrm{KE}$ and $\mathrm{KP}, \mathrm{F}_{1}$ hybrids and outbred mice. There was no difference between hybrid and outbred females. Mice from the KE strain had stronger reaction than $F_{1}$ or outbred animals, while KP females, which have low fertility, had significantly smaller DCR. Uterine sensitivity to trauma on the 3rd, 4th or 5th day of pseudopregnancy was compared in $\mathrm{KE}$ and $\mathrm{KP}$ females. It was concluded that the relatively low and prolonged sensitivity of the uterus to mechanical stimuli in the KP strain may indicate an oestrogen deficiency.
\end{abstract}

\section{INTRODUCTION}

Fertility of two inbred mouse strains $\mathrm{KE}$ and $\mathrm{KP}$, their $\mathrm{F}_{1}$ hybrids and the outbred stock from which they were derived has been studied in considerable detail. Extensive data are available on their sperm count, morphology of spermatozoa, oestrous cycle, ovulation and fertilization rate, embryo survival, litter size, etc. (review in Krzanowska, 1965). KP females have a low rate of implantation and low embryo survival, while KE females differ very little from $F_{1}$ or outbred animals (Krzanowska, 1960a, b). The purpose of this investigation has been to compare the decidual cell reaction (DCR) evoked by mechanical trauma in $\mathrm{KE}, \mathrm{KP}, \mathrm{F}_{1}$ and outbred mice in an attempt to obtain information on the mechanism of fertility depression in the KP females. Experimentally-induced DCR closely resembles the changes occurring in the uterus during implantation and requires the same hormonal milieu in the rat (Yochim \& DeFeo, 1962, 1963) and, most likely, in the mouse (Finn, 1966).

\section{MATERIALS AND METHODS}

Adult nulliparous $\mathrm{KE}, \mathrm{KP}$ and $\mathrm{F}_{1}$ females were mated with vasectomized males of an unrelated outbred stock and examined every morning for the presence of vaginal plugs. Plug date was considered the 1st day of pseudopregnancy. On the 4th day, between 14.00 and 16.00 hours, the left uterine horn was mechanically traumatized using a broken-tip needle (Yochim \& DeFeo, 1962). The right horn was left intact and served as a control. On the 9 th day the females were autopsied and the uterine horns weighed on a torsion

* Present address: Worcester Foundation for Experimental Biology, Shrewsbury, Mass., U.S.A. 
balance to the nearest milligram. The data on DCR of outbred mice were obtained in the same manner as in a previous study (Bartke, 1968).

Groups of KE and KP mice were traumatized on the afternoon of the 3rd day or the morning of the 5 th day to test the possibility that altered timing of uterine sensitivity in KP females was responsible for their low DCR. Autopsy was performed 5 days after traumatization, as before.

Traumatization on the 4 th day

\section{RESULTS}

Decidual cell reaction took place in all horns which were traumatized on the 4th day. The extent of DCR, as measured by the weight of the traumatized horn, was the same in outbred and $F_{1}$ mice. There was no difference between reciprocal hybrids. The reaction of $\mathrm{KP}$ females was markedly weaker than that of $\mathrm{KE}, \mathrm{F}_{1}$ or outbred mice $(P<0.01)$, while the reaction of $\mathrm{KE}$ females was stronger than that in any of the remaining groups $(P<0 \cdot 01)($ Table 1$)$.

TABLE 1

DEGIDUAL CELl REAGTION IN KE, KP, $\mathrm{F}_{1}$ AND OUTBRED MICE (MEANS \pm S.E.)

\begin{tabular}{l|c|c|c|c|c}
\hline \multicolumn{1}{c|}{ Strain } & $\begin{array}{c}\text { No. of } \\
\text { mice }\end{array}$ & $\begin{array}{c}\text { Age at plug } \\
\text { formation } \\
\text { (weeks) }\end{array}$ & $\begin{array}{c}\text { Weight of intact } \\
\text { uterine horn } \\
(\mathrm{mg})\end{array}$ & $\begin{array}{c}\text { Weight of traumatized } \\
\text { uterine horn } \\
(\text { mg) }\end{array}$ & $\begin{array}{c}\text { Ratio } \\
\text { traumatized } \\
\text { /intact }\end{array}$ \\
\hline KE & 11 & $12 \pm 1$ & $34 \pm 1$ & $297 \pm 22$ & $8 \cdot 7$ \\
KP & 9 & $12 \pm 1$ & $39 \pm 2$ & $104 \pm 12$ & $2 \cdot 7$ \\
F $_{1}$ (KEKP) & 14 & $13 \pm 1$ & $40 \pm 1$ & $199 \pm 19$ & $5 \cdot 0$ \\
F (KPKE) $_{\text {Outbred* }}$ & 7 & $11 \pm 1$ & $37 \pm 2$ & $195 \pm 24$ & $5 \cdot 3$ \\
\hline
\end{tabular}

* Data from Bartke (1968).

TABLE 2

DECIDUAL CELL REACTION OF KE AND KP FEMALES TRAUMATIZED ON THE 3RD, 4TH OR 5TH DAY OF PSEUDOPREGNANCY (MEANS \pm S.E.)

\begin{tabular}{c|c|c|c|c|c}
\hline Strain & $\begin{array}{c}\text { Time of } \\
\text { trauma }\end{array}$ & $\begin{array}{c}\text { No. of } \\
\text { mice }\end{array}$ & $\begin{array}{c}\text { Age } \\
\text { (weeks) }\end{array}$ & $\begin{array}{c}\text { Weight of intact } \\
\text { uterine horn } \\
(\mathrm{mg})\end{array}$ & $\begin{array}{c}\text { Weight of traumatized } \\
\text { uterine horn } \\
(\mathrm{mg})\end{array}$ \\
\hline \multirow{2}{*}{$\mathrm{KE}$} & 3rd day & 5 & $11 \pm 1$ & $27 \pm 2$ & $140 \pm 36\} P<0 \cdot 01$ \\
& 4th day & 11 & $12 \pm 1$ & $34 \pm 1$ & $297 \pm 22\} P<0 \cdot 01$ \\
& 5th day & 4 & $10 \pm 1$ & $30 \pm 3$ & $143 \pm 35\} P<1$ \\
& 3rd day & 4 & $8 \pm 1$ & $32 \pm 2$ & $122 \pm 24\}$ N.S. \\
& 4th day & 9 & $12 \pm 1$ & $39 \pm 2$ & $104 \pm 12$ \\
& 5th day & 5 & $10 \pm 1$ & $42 \pm 1$ & $109 \pm 18\}$ N.S. \\
\hline
\end{tabular}

Traumatization on the $3 r d$ or 5 th day

In the KE strain DCR resulting from trauma on the 3rd or 5th day was significantly weaker than that observed after trauma on the 4th day $(P<0.01)$. No DCR was observed in two of five mice traumatized on the 3rd day. In the 
KP females DCR was observed in all traumatized horns and the extent of decidual reaction did not differ significantly between the mice traumatized on the 3rd, 4th or 5th day (Table 2).

\section{DISCUSSION}

The results of this study demonstrated drastic differences in the decidual cell reaction between KE, KP and $F_{1}$ or outbred mice. Presumably KP and KE mice possess somewhat opposite genotypes with respect to the many genes controlling uterine sensitivity. Outbred mice from the stock of which KP and $\mathrm{KE}$ strains were derived, and $\mathrm{F}_{1}$ hybrids between them, had reactions intermediate between those of KP and KE females.

Results of the present investigation are in good agreement with earlier data on fertility of the strains employed. Outbred and $\mathbf{F}_{\mathbf{1}}$ females had high implantation rates, good embryo survival and strong DCR. KE females had strictly comparable implantation and embryo survival rates but stronger DCR. This would indicate that, with respect to the hormonal milieu determining uterine changes in early gestation, $\mathrm{KE}, \mathrm{F}_{1}$ and outbred females are all above the threshold necessary for essentially normal sensitivity and fertility. In KP females, implantation and embryo survival were poor and the experimentallyinduced DGR weak, suggesting the impairment of all uterine changes associated with implantation and early gestation.

Yochim \& DeFeo (1963) demonstrated that, in ovariectomized female rats, normal timing of uterine sensitivity and optimal decidual growth occur only when progesterone and oestrogen are administered in proper amounts and proper ratio. When there was no, or too little, oestrogen the reaction was reduced but the period of uterine sensitivity was prolonged. The low and prolonged sensitivity found in KP females may therefore be due to a relative oestrogen deficiency. Further support for this hypothesis comes from the observations that the period of vaginal cornification is shorter in cycling $\mathrm{KP}$ females than in KE, $F_{1}$ or outbred mice (Krzanowska, 1964, and unpublished results) and that vaginal opening is established later in KP than in KE or $F_{1}$ females namely, at the age of 34 days rather than 30 or 31 days (Wojtusiak, 1968).

The hormonal requirements for implantation and pregnancy maintenance as well as for the DCR in the mouse have not been completely elucidated. Experiments with mice ovariectomized late during the pregnancy suggested that progesterone alone is sufficient to maintain gestation (Rubinstein \& Forbes, 1963). However, both progesterone and oestrogen seem to be necessary during the early stages of pregnancy and especially at the time of implantation (Jaitly, Robson, Sullivan \& Wilson, 1965; Finn, 1966). On the other hand, Smithberg \& Runner (1956) reported implantation in mice ovariectomized on the 2nd or 3rd day post coitum and given progesterone alone, although the mean number of implants was reduced. Finn (1966) demonstrated that DCR elicited by crushing the uterine horn occurs in ovariectomized mice given progesterone alone, whereas oestrogen is required in addition to obtain DCR from intrauterine arachis oil injections. 
Note added in proof: Recently Moore-Smith and Biggers provided very strong evidence that the oestrogen is necessary for implantation in the mouse. (Moore-Smith, D. \& Biggers, J. D. (1968) The oestrogen requirement for implantation and the effect of its dose on the implantation response in the mouse. F. Endocr. 41, 1.)

\section{ACKNOWLEDGMENT}

The author wishes to express his sincere thanks to Dr H. Krzanowska for many helpful comments.

\section{REFERENCES}

BARTKE, A. (1968) Effect of an IUD on implantation and decidual reaction in different strains of mice. J. Reprod. Fert. $15,185$.

Fins, C. A. (1966) Endocrine control of endometrial sensitivity during the induction of the decidual cell reaction in the mouse. F. Endocr. 36, 239.

Jaitly, K. D., Robson, J. M., Sullivan, F. M. \& Wilson, C. (1965) Hormonal requirements for the maintenance of gestation in hypophysectomized mice. F. Endocr. 34, iv.

Krzanowska, H. (1960a) Studies on heterosis. II. Fertilization rate in inbred lines of mice and their crosses. Folia biol., Krakbw, 8, 269.

KRzANowska, H. (1960b) Early embryonal mortality in inbred lines of mice and their crosses. Bull. Soc. belge Gynéc. Obstét. 30, 719.

KRzanowska, H. (1964) Studies on heterosis. III. The course of the sexual cycle and the establishment of pregnancy in mice, as affected by the type of mating. Folia biol., Kraków, 12, 415.

Krzanowska, H. (1965) Mouse News Lett. 32, 54.

Rubinstein, L. \& Forbes, T. R. (1963) Maintenance of pregnancy with subcutaneous pellets of progesterone in ovariectomized mice. Proc. Soc. exp. Biol. Med. 113, 1043.

SMITHBERG, M. \& RUNNER, M. N. (1956) The induction and maintenance of pregnancy in prepubertal mice. J. exp. Zool. 133, 441 .

Wojtusiak, D. (1968) Spatial orientation of inbred and $F_{1}$ hybrid mice in a maze. Folia biol., Kraków (In press).

Yoснім, J. M. \& DeFeo, V. J. (1962) Control of decidual growth in the rat by steroid hormones of the ovary. Endocrinology, 71, 134.

Yochim, J. M. \& DEFEO, V. J. (1963) Hormonal control of the onset, magnitude and duration of uterine sensitivity in the rat by steroid hormones of the ovary. Endocrinology, 72, 317. 